The unabridged version of this article can be found at www.asco.org/ guidelines/larynx/unabridged.

From the American Society of Clinical Oncology, Alexandria, VA

Submitted May 15, 2006; accepted May 19, 2006; published online ahead of print at www.jco.org on July 10, 2006.

Adopted on February 28, 2006, by the American Society of Clinical Oncology.

Authors' disclosures of potential conflicts of interest and author contributions are found at the end of this article.

Address reprint requests to American Society of Clinical Oncology, Cancer Policy and Clinical Affairs, 1900 Duke Street, Suite 200, Alexandria, VA 22314; e-mail: guidelines@asco.org. (C) 2006 by American Society of Clinical Oncology

0732-183X/06/2422-3693/\$20.00 DOI: 10.1200/JCO.2006.07.4559

\title{
American Society of Clinical Oncology Clinical Practice Guideline for the Use of Larynx-Preservation Strategies in the Treatment of Laryngeal Cancer
}

David G. Pfister, Scott A. Laurie, Gregory S. Weinstein, William M. Mendenhall, David J. Adelstein, K. Kian Ang, Gary L. Clayman, Susan G. Fisher, Arlene A. Forastiere, Louis B. Harrison, Jean-Louis Lefebvre, Nancy Leupold, Marcy A. List, Bernard O. O'Malley, Snehal Patel, Marshall R. Posner, Michael A. Schwartz, and Gregory T. Wolf

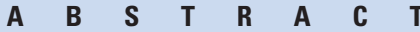

\section{Purpose}

To develop a clinical practice guideline for treatment of laryngeal cancer with the intent of preserving the larynx (either the organ itself or its function). This guideline is intended for use by oncologists in the care of patients outside of clinical trials.

\section{Methods}

A multidisciplinary Expert Panel determined the clinical management questions to be addressed and reviewed the literature available through November 2005, with emphasis given to randomized controlled trials of site-specific disease. Survival, rate of larynx preservation, and toxicities were the principal outcomes assessed. The guideline underwent internal review and approval by the Panel, as well as external review by additional experts, members of the American Society of Clinical Oncology (ASCO) Health Services Committee, and the ASCO Board of Directors.

\section{Results}

Evidence supports the use of larynx-preservation approaches for appropriately selected patients without a compromise in survival; however, no larynx-preservation approach offers a survival advantage compared with total laryngectomy and adjuvant therapy with rehabilitation as indicated.

\section{Recommendations}

All patients with T1 or T2 laryngeal cancer, with rare exception, should be treated initially with intent to preserve the larynx. For most patients with T3 or T4 disease without tumor invasion through cartilage into soft tissues, a larynx-preservation approach is an appropriate, standard treatment option, and concurrent chemoradiotherapy therapy is the most widely applicable approach. To ensure an optimum outcome, special expertise and a multidisciplinary team are necessary, and the team should fully discuss with the patient the advantages and disadvantages of larynx-preservation options compared with treatments that include total laryngectomy.

\section{J Clin Oncol 24:3693-3704. (C) 2006 by American Society of Clinical Oncology}

\section{INTRODUCTION}

In 2005, an estimated 9,880 new cases of laryngeal cancer will be diagnosed in the United States, accounting for 3,770 deaths. ${ }^{1}$ Squamous cell carcinoma is the predominant histologic type, and approximately $40 \%$ of patients will have stage III or IV disease when first evaluated. ${ }^{2}$ Most cases of laryngeal cancer are associated with a history of tobacco and/or alcohol use, so the treatment of patients is complicated by medical comorbidity and the development of second primary cancers. ${ }^{3-5}$ Given the fundamental role the larynx plays in human speech and communication, determining the optimal management of laryngeal cancers must involve consideration of both survival and the functional consequences of a given treatment approach. The potential morbidity of curative treatment is a special consideration when total laryngectomy, either for primary therapy or as salvage treatment, is the recommendation. Total laryngectomy is widely recognized as one of the surgical procedures most feared by patients. Social isolation, job loss, and depression are common sequelae. ${ }^{6,7}$ Pioneering work on patient preferences showed that approximately $25 \%$ of healthy individuals interviewed were willing to trade a 20\% absolute difference in survival for the opportunity to save their voice. ${ }^{8}$ Different voice rehabilitations exist, ${ }^{9}$ but many patients are dissatisfied with the results and report associated restrictions in their 
daily lives. Although the impact of the procedure on voice often receives the greatest attention, the presence of the stoma may adversely affect quality of life as much, if not more. ${ }^{10}$ Accordingly, there has been keen interest in the development and refinement of organpreservation therapies, such as radiation therapy alone, the combination of chemotherapy and radiation therapy (chemoradiotherapy therapy), and function-preserving partial laryngectomy procedures. With all three of these approaches, total laryngectomy is reserved for tumor recurrence.

The American Society of Clinical Oncology (ASCO) fully appreciates the controversy about how to best achieve the dual goals of cure and preservation of function for patients with laryngeal cancer. As a service to patients, to its members, and to practicing physicians generally, ASCO convened an Expert Panel under the auspices of the Health Services Committee to develop recommendations regarding the appropriate application of larynx-preservation therapies.

Accordingly, ASCO considers adherence to this guideline to be voluntary, with the ultimate determination regarding its application to be made by the physician in light of each patient's individual circumstances. In addition, the guideline describes administration of therapies in clinical practice; it cannot be assumed to apply to interventions performed in the context of clinical trials, given that clinical studies are designed to test innovative and novel therapies in a disease and setting for which better therapy is needed. Because guideline development involves a review and synthesis of the latest literature, a practice guideline also serves to identify important questions for further research and those settings in which investigational therapy should be considered.

\section{QUESTIONS}

The following questions about squamous cell laryngeal cancer were addressed by the Panel:

(1) What are the larynx-preservation treatment options for limited stage (T1, T2) primary site disease that do not compromise survival? What are the considerations in selecting among them?

(2) What are the larynx-preservation treatment options for advanced stage (T3, T4) primary site disease that do not compromise survival? What are the considerations in selecting among them?

(3) What is the appropriate treatment of the regional cervical nodes for patients with laryngeal cancer who are treated with an organ-preservation approach?

(4) Are there methods for prospectively selecting patients with laryngeal cancer to increase the likelihood of success of larynx preservation?

\section{METHODS}

The members of the Expert Panel were selected for their expertise in clinical medicine; medical, radiation, and surgical oncology; diagnostic imaging; clinical research; outcomes/health services research; and related disciplines (biostatistics, quality of life) with a focus on expertise in head and neck and laryngeal cancer (Appendix A). To enhance the focus of the published guideline on the implications for clinical practice, the methodology of the guideline development is available online, at both www.jco.org and www.asco.org.

\section{GUIDELINE FOR LARYNX-PRESERVATION TREATMENT}

We have summarized the recommended treatment strategies by $\mathrm{T}$ stage, along with the basis for the recommendations and the quality of the supporting evidence (Table 1). A complete review of the literature and discussion of study results are available online.

\section{What are the larynx-preservation treatment options for limited stage (T1, T2) primary site disease that do not compromise survival? What are the considerations in selecting treatment options in this setting?}

Evidence base. There are no randomized studies in which radiation therapy was compared with conservation surgery with respect to local control or survival for patients with limited-stage laryngeal cancer. Similarly, there are no randomized controlled data on comparison of functional outcomes, specifically the quality of voice and swallowing ability, after surgery or radiation therapy for patients with this stage of disease.

The recommendations to address these questions are based on evidence from prospective and retrospective cohort studies. ${ }^{11-75}$ The recommendations for $\mathrm{T} 2 \mathrm{~N}+$ disease are based on data from randomized controlled trials of chemoradiotherapy therapy (with either induction or concurrent chemotherapy compared with radiation therapy alone or surgery followed by adjuvant radiation therapy). ${ }^{77,78}$ The outcomes assessed included overall survival, disease-free survival, rates of laryngeal preservation, local-regional control, toxicity of therapy, and cost.

Limited-stage disease represents a spectrum. Treatment selection can be challenging, as the evidence base for most decisions is derived from nonrandomized studies and various factors need to be considered when choosing therapy. Selected examples for glottic cancer are illustrative. If voice outcome is predicted to be good after endoscopic laser resection for a $\mathrm{T} 1$ glottic cancer (eg, a superficial tumor located in the middle third of the cord, especially on its free edge), then use of this modality is more efficient and thus preferred. However, lesions that are indistinct, especially those arising in the context of widespread, abnormal-appearing mucosa, are more suitable for radiation therapy than for surgery. Radiation therapy is preferred by many clinicians for treatment of T2 glottic carcinoma characterized as superficial on radiographic imaging, with preserved cord mobility, as local control rates are high and anticipated functional outcomes are good. But some investigators have noted compromised survival after the failure of radiation therapy in $\mathrm{T} 2$ glottic carcinoma indicating the importance of obtaining initial local control. ${ }^{56,59}$ As such, supracricoid partial laryngectomy with cricohyoidoepliglottopexy remains a reasonable alternative for patients with a $\mathrm{T} 2$ glottic carcinoma who after pretreatment counseling would be willing to sacrifice voice quality in an effort to improve local control. Induction chemotherapy has been investigated as treatment for patients with limited-stage laryngeal cancer. However, insufficient data are currently available to recommend such an approach outside the context of a clinical trial.

\section{Recommendations}

- All patients with T1-T2 laryngeal cancer should be treated, at least initially, with intent to preserve the larynx.

- T1-T2 laryngeal cancer can be treated with radiation or larynx-preservation surgery with similar survival outcomes. Selection of treatment depends on patient factors, local expertise, 


\begin{tabular}{|c|c|c|c|c|}
\hline \multirow[b]{2}{*}{ Type of Cancer } & \multicolumn{2}{|c|}{ Organ-Preservation Strategy } & \multirow[b]{2}{*}{ Basis for Recommendation } & \multirow[b]{2}{*}{ Quality of Evidence } \\
\hline & Recommended & Other Options & & \\
\hline $\begin{array}{l}\text { T1 cancer of the glottis: } \\
\text { T1- tumor limited to the vocal cord(s) } \\
\text { (may involve anterior or posterior } \\
\text { commisure) with normal mobility } \\
\text { T1a-tumor limited to one vocal cord } \\
\text { T1b-tumor involves both vocal cords }\end{array}$ & $\begin{array}{l}\text { Endoscopic resection } \\
\text { (selected patients) OR } \\
\text { radiation therapy }\end{array}$ & $\begin{array}{l}\text { Open organ- } \\
\text { preservation } \\
\text { surgery }\end{array}$ & $\begin{array}{l}\text { High local control rates and quality } \\
\text { of voice after endoscopic } \\
\text { resection compared with } \\
\text { radiation therapy; possible cost } \\
\text { savings; ability to reserve } \\
\text { radiation for possible second } \\
\text { primary cancers of the upper } \\
\text { aerodigestive tract; however, } \\
\text { not suitable for all patients }\end{array}$ & $\begin{array}{l}\text { Comparison of outcomes } \\
\text { from case series/ } \\
\text { prospective single-arm } \\
\text { studies }\end{array}$ \\
\hline $\begin{array}{l}\text { T2 cancer of the glottis, } \\
\text { favorable }{ }^{*} \text { :T2-tumor } \\
\text { extends to supraglottis } \\
\text { and/or subglottis, or with } \\
\text { impaired vocal cord mobility }\end{array}$ & $\begin{array}{l}\text { Open organ-preservation } \\
\text { surgery OR radiation } \\
\text { therapy }\end{array}$ & $\begin{array}{l}\text { Endoscopic resection } \\
\text { (selected patients) }\end{array}$ & $\begin{array}{l}\text { Open organ-preservation surgery is } \\
\text { associated with highest local } \\
\text { control rates; however, leads to } \\
\text { permanent hoarseness; local } \\
\text { control rates after radiation therapy } \\
\text { are also high, and functional } \\
\text { outcomes may be better }\end{array}$ & $\begin{array}{l}\text { Comparison of outcomes } \\
\text { from case series/ } \\
\text { prospective single-arm } \\
\text { studies }\end{array}$ \\
\hline T2 cancer of the glottis, unfavorable* & $\begin{array}{l}\text { Open organ-preservation } \\
\text { surgery OR concurrent } \\
\text { chemoradiation therapy } \\
\text { (selected patients with } \\
\text { node-positive disease) }\end{array}$ & $\begin{array}{l}\text { Radiation therapy } \\
\text { Endoscopic } \\
\text { resection (selected } \\
\text { patients) }\end{array}$ & $\begin{array}{l}\text { Higher local control rates after } \\
\text { surgery compared with radiation } \\
\text { therapy alone; quality of voice } \\
\text { after therapy of less concern if } \\
\text { vocal cord function is } \\
\text { irreversibly compromised by } \\
\text { tumor invasion; , endoscopic } \\
\text { surgery requires careful patient } \\
\text { selection } \\
\text { For patients with T2 } \mathrm{N}+ \\
\text { disease, evidence from } \\
\text { randomized trials supports } \\
\text { concurrent chemoradiation } \\
\text { therapy as an organ- } \\
\text { preservation option }\end{array}$ & $\begin{array}{l}\text { Comparison of outcomes } \\
\text { from case series/ } \\
\text { prospective single-arm } \\
\text { studies; randomized } \\
\text { controlled clinical trials } \\
\text { comparing concurrent } \\
\text { chemoradiation therapy, } \\
\text { and/or induction } \\
\text { chemotherapy followed } \\
\text { by radiation, and/or } \\
\text { radiation therapy alone, } \\
\text { and/or surgery followed } \\
\text { by radiation }\end{array}$ \\
\hline $\begin{array}{l}\text { T1-T2 cancer of the supraglottis, } \\
\text { favorable*:T1-tumor } \\
\text { limited to one subsite of supraglottis } \\
\text { with normal vocal cord mobility } \\
\text { T2-tumor invades mucosa of more } \\
\text { than one adjacent subsite of supraglottis } \\
\text { or glottis or region outside the } \\
\text { supraglottis (eg, mucosa of base of } \\
\text { tongue, vallecula, medial wall of pyriform } \\
\text { sinus) without fixation of the larynx }\end{array}$ & $\begin{array}{l}\text { Open organ-preservation } \\
\text { surgery OR radiation } \\
\text { therapy }\end{array}$ & $\begin{array}{l}\text { Endoscopic resection } \\
\text { (selected patients) }\end{array}$ & $\begin{array}{l}\text { Open organ-preservation surgery } \\
\text { associated with highest local } \\
\text { control rates; however, requires } \\
\text { temporary tracheostomy and } \\
\text { may lead to increased risk of } \\
\text { aspiration after therapy; local } \\
\text { control rates after radiation } \\
\text { therapy are also high, and } \\
\text { functional outcomes may be } \\
\text { better }\end{array}$ & $\begin{array}{l}\text { Comparison of outcomes } \\
\text { from case series/ } \\
\text { prospective single-arm } \\
\text { studies }\end{array}$ \\
\hline $\begin{array}{l}\text { T2 cancer of the supraglottis, } \\
\text { unfavorable* }\end{array}$ & $\begin{array}{l}\text { Open organ-preservation } \\
\text { surgery OR concurrent } \\
\text { chemoradiation therapy } \\
\text { (selected patients with } \\
\text { node-positive disease) }\end{array}$ & $\begin{array}{l}\text { Radiation therapy } \\
\text { Endoscopic } \\
\text { resection (selected } \\
\text { patients) }\end{array}$ & $\begin{array}{l}\text { Open organ-preservation surgery } \\
\text { is more likely to yield higher } \\
\text { local control rates than radiation } \\
\text { therapy; for patients with T2 } \\
\mathrm{N}+\text { disease, evidence from } \\
\text { randomized trials supports } \\
\text { concurrent chemoradiation } \\
\text { therapy as an organ- } \\
\text { preservation option }\end{array}$ & $\begin{array}{l}\text { Comparison of outcomes } \\
\text { from case series/ } \\
\text { prospective single-arm } \\
\text { studies; randomized } \\
\text { controlled clinical trials } \\
\text { comparing concurrent } \\
\text { chemoradiation therapy, } \\
\text { and/or induction chemo- } \\
\text { therapy followed by } \\
\text { radiation, and/or radiation } \\
\text { therapy alone, and/or } \\
\text { surgery followed by } \\
\text { radiation }\end{array}$ \\
\hline $\begin{array}{l}\text { T3-T4 cancers of the glottis or supraglottis: } \\
\text { T3 glottis- tumor limited to the larynx } \\
\text { with vocal cord fixation, and/or invades } \\
\text { paraglottic space, and/or minor thyroid } \\
\text { cartilage erosion (eg, inner cortex) } \\
\text { T3 supraglottis- tumor limited to larynx } \\
\text { with vocal cord fixation and/or invades } \\
\text { any of the following: postcricoid area, } \\
\text { pre-epiglottic tissues, paraglottic space, } \\
\text { and/or minor thyroid cartilage erosion } \\
\text { (eg, inner cortex) } \\
\text { T4a glottis or supraglottis- tumor } \\
\text { invades through the thyroid cartilage } \\
\text { and/or invades tissues beyond the larynx } \\
\text { (eg, trachea, soft tissues of neck } \\
\text { including deep extrinsic muscle of the } \\
\text { tongue, strap muscles, thyroid, or } \\
\text { esophagus) } \\
\text { Thb glottis or supraglottis-tumor } \\
\text { invades prevertebral space, encases } \\
\text { carotid artery, or invades mediastinal } \\
\text { structures }\end{array}$ & $\begin{array}{l}\text { Concurrent chemoradiation } \\
\text { therapy OR open organ- } \\
\text { preservation surgery (in } \\
\text { highly selected patients) }\end{array}$ & Radiation therapy & $\begin{array}{l}\text { Highest rate of larynx preservation } \\
\text { is associated with concurrent } \\
\text { chemoradiation therapy } \\
\text { compared with other radiation- } \\
\text { based approaches, at the cost } \\
\text { of higher acute toxicities but } \\
\text { without more long-term } \\
\text { difficulties in speech and } \\
\text { swallowing; when salvage total } \\
\text { laryngectomy incorporated, no } \\
\text { difference in overall survivali } \\
\text { organ preservation surgery is an } \\
\text { option in highly selected } \\
\text { patietns (eg, there are patients } \\
\text { with T3 supraglottic cancers } \\
\text { that have minimal or moderate } \\
\text { pre-epiglottic invasion and are } \\
\text { candidates for organ preserving } \\
\text { surgery) }\end{array}$ & $\begin{array}{l}\text { Randomized controlled } \\
\text { clinical trials comparing } \\
\text { concurrent chemoradia- } \\
\text { tion therapy, and/or } \\
\text { induction chemotherapy } \\
\text { followed by radiation, } \\
\text { and/or radiation therapy } \\
\text { alone; and/or surgery } \\
\text { followed by radiation; } \\
\text { comparison of outcomes } \\
\text { from case } \\
\text { series/prospective single- } \\
\text { arm studies }\end{array}$ \\
\hline $\begin{array}{l}{ }^{*} \text { A favorable T2 glottic lesion is defined } \\
\text { a deeply invasive tumor on radiographi } \\
\text { supraglottic lesion is defined as a T1 or T } \\
\text { with minimal involvement of the medial }\end{array}$ & the pyriform sinus. & ally ad & $\begin{array}{l}\text { I cord mobility. An unfavorable } \\
\text { aired cord mobility (indicating } \\
\text { preserved cord mobility, and/o } \\
\text { ive T2 suproglottic lesions are }\end{array}$ & $\begin{array}{l}\text { glottic lesion is defined as } \\
\text { eper invasion). A favorable } \\
\text { mor of the aryepiglottic fold } \\
\text { sidered unfavorable. }\end{array}$ \\
\hline
\end{tabular}

and the availability of appropriate support and rehabilitative services. Every effort should be made to avoid combining surgery with radiation therapy because functional outcomes may be compromised by combined-modality therapy; single-modality treatment is effective for limited-stage, invasive cancer of the larynx.
- Surgical excision of the primary tumor with intent to preserve the larynx should be undertaken with the aim of achieving tumor-free margins; so-called narrow-margin excision followed by postoperative radiation therapy is not an acceptable treatment approach. 
- Local tumor recurrence after radiation therapy may be amenable to salvage by organ-preservation surgery, but total laryngectomy will be necessary for a substantial proportion of patients, especially those with index T2 tumors.

- Concurrent chemoradiotherapy therapy may be used for larynx preservation for selected patients with stage III, T2 N+ cancers when total laryngectomy is the only surgical option, when the functional outcome after larynx-preservation surgery is expected to be unsatisfactory, or when surgical expertise in such procedures is not available.

- Limited-stage laryngeal cancer constitutes a wide spectrum of disease. The clinician must exercise judgment when recommending treatment in this category. For a given patient, factors that may influence the selection of treatment modality include extent and volume of tumor; involvement of the anterior commissure; lymph node metastasis; the patient's age, occupation, preference, and compliance; availability of expertise in radiation therapy or surgery; and history of a malignant lesion in the head and neck.

\section{What are the larynx-preservation treatment options for advanced stage $(T 3, T 4)$ primary site disease that do not compromise survival? What are the considerations in selecting among them?}

Evidence base. The recommendations to address these questions are based on evidence from randomized controlled trials of different radiation fractionation schedules, ${ }^{76}$ chemoradiotherapy therapy (either induction or concurrent) compared with radiation therapy alone or surgery followed by adjuvant radiation therapy, ${ }^{77-85}$ on meta-analysis or other secondary analysis of data from randomized clinical trials, ${ }^{86-88,102,105,108}$ and on prospective and retrospective cohort studies. $^{22,58,89-101,103,104,106,107}$ The outcomes evaluated included overall survival, disease-free survival, rates of laryngeal preservation, local-regional control, toxicity of therapy, and cost.

\section{Recommendations}

- Organ-preservation surgery, concurrent chemoradiotherapy therapy, and radiation therapy alone, all with further surgery reserved for salvage, offer potential for larynx preservation without compromising survival. Anticipated success rates for larynx preservation, associated toxicities, and suitability for a given patient will vary among these approaches. Selection of a treatment option will depend on patient factors, local expertise, and the availability of appropriate support and rehabilitation services.

- All patients should be evaluated regarding their suitability for a larynx-preservation approach, and they should be apprised of these treatment options. No larynx-preservation approach offers a survival advantage compared with total laryngectomy and appropriate adjuvant treatment (Table 2).

- A minority of patients with T3-T4 primary site disease will be suitable for specialized organ-preservation procedures, such as a supracricoid partial laryngectomy. The addition of postoperative radiation therapy will compromise anticipated functional outcomes. Induction chemotherapy before organ-preservation surgery is not recommended outside of a clinical trial.

- Concurrent chemoradiotherapy therapy offers a significantly higher chance of larynx preservation than does radiation therapy alone or induction chemotherapy followed by radiation, albeit at the cost of higher acute in-field toxicities (Table 3 ).

- The best available evidence supports the use of cisplatin as the drug of choice in this setting.

- There is insufficient evidence to indicate that survival or larynx-preservation outcomes are improved by the addition of induction chemotherapy before concurrent treatment or the use of concurrent chemotherapy with altered fractionated radiation therapy in this setting.

- For patients who desire larynx-preservation therapy but are not candidates for organ-preservation surgery or chemoradiotherapy therapy, radiation therapy alone is an appropriate treatment. With this last approach, survival is similar to that associated with chemoradiotherapy therapy when salvage surgery is incorporated, but the likelihood of larynx preservation is lower.

\section{What is the appropriate treatment of the regional cervical nodes in patients with laryngeal cancer who are treated with an organ-preservation approach?}

Evidence base. There are no randomized studies that address treatment of the neck for limited-stage disease in the primary site. The randomized studies of more advanced primary disease do not focus on treatment of the neck as a primary end point.

The recommendations to address this question are based on evidence from derivative analyses of randomized controlled trials of chemoradiotherapy (either induction or concurrent) compared with radiation therapy alone or surgery followed by adjuvant radiation therapy, ${ }^{125,140}$ a randomized trial comparing the different types of neck dissection, ${ }^{113}$ and on prospective and retrospective cohort studies. ${ }^{25,35,66,109,124,126-139,141,142}$ With respect to adjuvant therapy, evidence was drawn from randomized controlled trials of radiation therapy compared with concurrent chemoradiotherapy. ${ }^{143-145}$ The outcomes assessed included overall survival, disease-free survival, local-regional control, and toxicity of therapy.

\section{Recommendations}

- Most patients with T1-T2 lesions of the glottis and clinically negative cervical nodes (N0) do not require routine elective treatment of the neck.

- Patients with advanced lesions of the glottis and all patients with supraglottic lesions should have elective treatment of the neck, even if clinically N0.

- Patients with clinically involved regional cervical nodes (N1) who are treated with definitive radiation therapy or chemoradiotherapy therapy and who have a complete clinical response do not require elective neck dissection. Neck dissection should be performed for patients who do not have a complete clinical response to radiation therapy.

- Surgical treatment of the neck is recommended for patients with $\mathrm{N} 2$ or N3 disease who are treated with definitive radiation therapy or chemoradiotherapy therapy, regardless of response. Some surgeons and patients are reluctant to risk the morbidity of neck dissection, given the prospect of a negative pathologic diagnosis in most cases, but there is no standard imaging approach in this setting that has been validated to significantly improve on this decision-making process. Salvage surgery for recurrent disease in the neck is rarely successful if subsequently required in this setting. These two points should be discussed with all patients who have an 


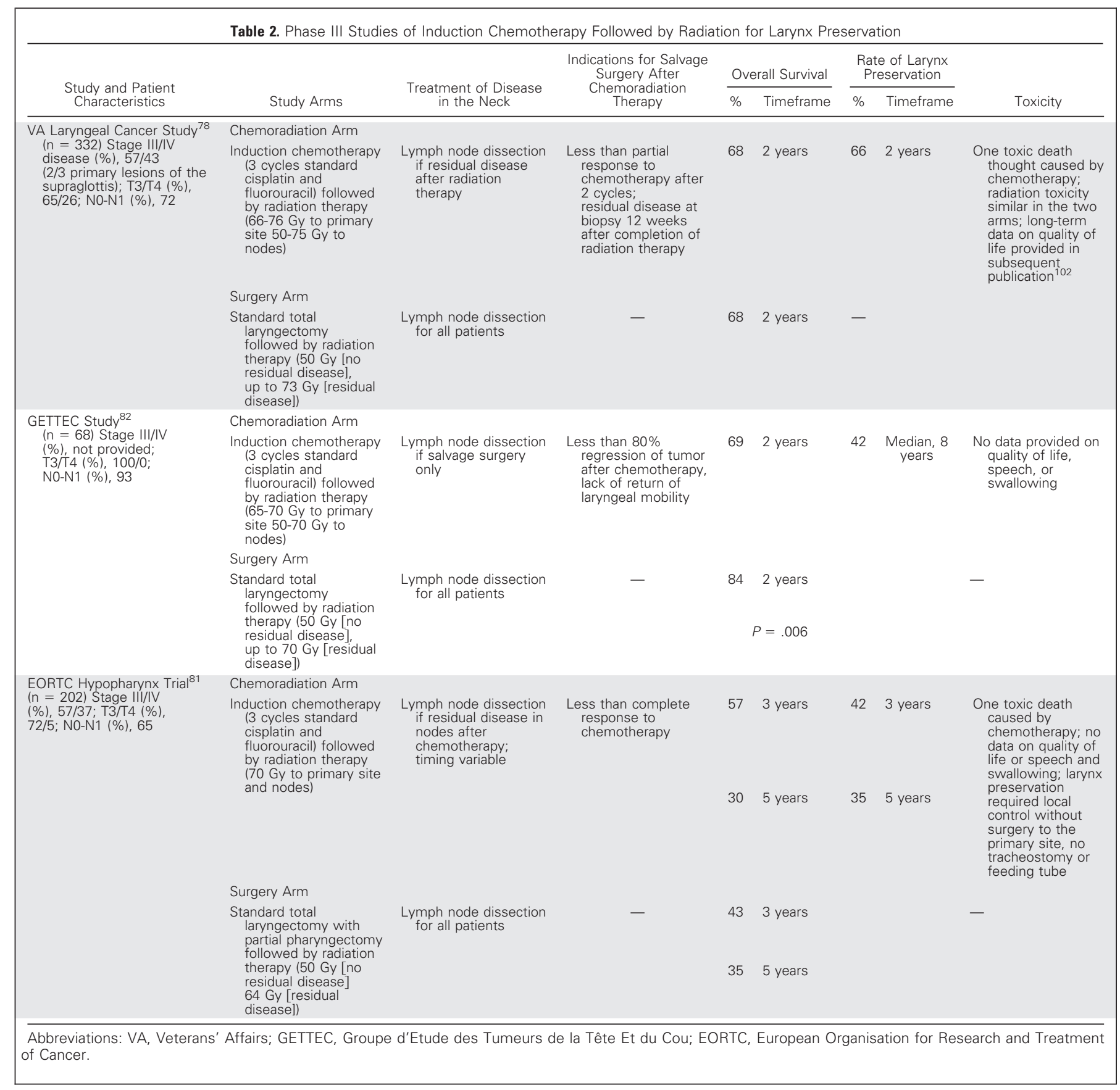

apparent complete clinical response to radiation therapy or chemoradiotherapy therapy and choose to be followed up with expectant observation.

- Patients with clinically involved cervical nodes who are treated with surgery for the primary lesion should have neck dissection. If there are poor-risk features, adjuvant concurrent chemoradiotherapy therapy is indicated.

\section{Are there methods for prospectively selecting patients with laryngeal cancer to increase the likelihood of successful larynx preservation?}

Evidence base. The recommendations addressing this question are based on evidence from prospective and retrospective cohort stud- ies of clinical, radiographic, and/or pathologic parameters associated with clinical outcomes $44,47,62,73,89,91,146,147,149,151-168$ and on derivative analyses of a randomized controlled trial. ${ }^{148,150,169-171}$ The outcomes assessed included overall survival, disease-free survival, local-regional control, and rates of laryngeal preservation.

\section{Recommendations}

- There are no validated markers that consistently predict outcomes of larynx-preservation therapy. However, patients with tumor penetration through cartilage into soft tissues are considered poor candidates for a larynx-preservation approach. Primary surgery, usually total laryngectomy, is commonly recommended in this setting. 


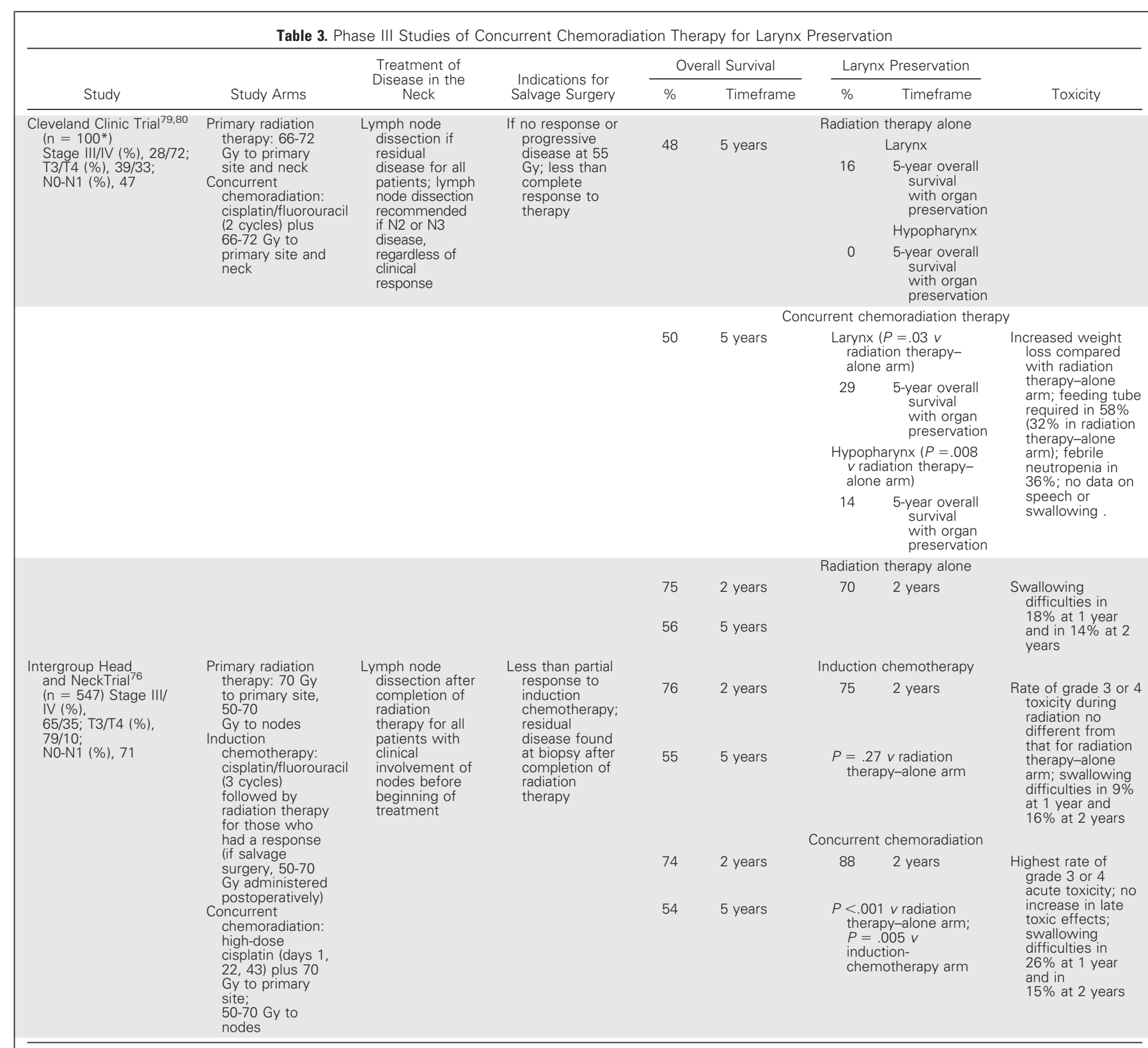

*Data given for all enrolled patients; 52 had laryngeal/hypopharyngeal cancer.

- Selection of therapy for an individual patient requires assessment by a multidisciplinary team, as well as consideration of patient comorbidity, psychosocial situation and preferences, and local therapeutic expertise.

- Continued cigarette smoking appears to be associated with a worse outcome after radiation therapy. Patients should be encouraged to abstain from smoking after diagnosis and throughout treatment.

\section{FINAL COMMENTS}

Larynx-preservation therapy is intended to offer improved function and quality of life for patients with laryngeal cancer, without compro- mising survival. Our review of the data indicated that there is commonly more than one treatment option to consider. A thorough discussion of the risks and benefits of larynx-preservation therapy is crucial. Organ-preservation treatments can be difficult to administer, given that many patients have underlying medical comorbidity. Optimal patient selection increases the likelihood of a successful outcome. Effective application of larynx-preservation treatment requires special expertise and a specialized support team. A typical treatment team will include expertise in head and neck surgery, radiation therapy, medical oncology, pathology, nursing, speech and swallowing physiology/rehabilitation, audiology, social services, nutrition, tobacco cessation, and management of relevant medical comorbidities.

Many important management decisions have not been addressed by randomized trials or require further clarification. Reliable 
biologic markers and imaging techniques to facilitate assessment of patient prognosis and response to therapy are needed to guide therapy and select the patients most appropriate for organ-preserving approaches. Defining optimal treatment combinations, including the role of neoadjuvant/induction, concurrent, and adjuvant therapy, as well as newer targeted therapies, is a priority. The role of more targeted radiation approaches and newer fractionation schedules, the timing of surgery for persistent disease, and optimal surveillance for recurrence and prevention of second primary cancers are key research areas. Practical assessments and interventions for nutrition, speech, swallowing, risk-factor modification, and rehabilitation/reconstruction are needed. The Expert Panel believes that commitment to and support of relevant and important randomized studies will be fundamental to addressing these issues. The thoughtful incorporation of relevant correlative studies, such as tissue-specific investigations, into the design of randomized studies will maximize the value of the latter.

When treatments yield similar survival end points, other outcomes, such as function, quality of life, and cost, become increasingly relevant. For example, speech and swallowing are highly complex, finely coordinated neuromuscular processes, and may be disrupted by both the disease itself and its therapy. Preservation of the laryngeal structure is not considered a functional success if persistent dysphagia, aspiration, or chronic tracheostomy results from organ-preserving therapy. All organ-sparing therapies are not the same with regard to their anticipated functional and quality of life outcomes. Yet, as is the case with more traditional biomedical end points, randomized, primary site-specific data comparing patient-reported outcomes are limited.

Available information highlights some issues to consider. Differences in outcome between surgical and radiation-based approaches are not necessarily found on all quality-of-life domains, ${ }^{26,102}$ and some that do may be primary site dependent. ${ }^{172}$ How each patient perceives an adverse sequela of treatment is variable. Permanent gastrostomy or stoma is often a greater concern to patients than loss of speech ${ }^{10,173}$; other quality-of-life domains (eg, emotional, social, financial) besides the functional one may be affected by the disease and its treatment and deserve attention. Underestimation of substantial functional morbidity and treatment-related toxicities such as dysphagia is a risk if patients are not followed up for longer time periods. ${ }^{30,174-176}$ Careful assessment of such outcomes is crucial to guide subsequent protocol development in hopes of minimizing the morbidity of treatment without compromising efficacy. ${ }^{177,178}$

The thoughtful incorporation of valid pretreatment and longitudinal post-treatment functional and quality-of-life assessments will enhance the value of future larynx-preservation studies. Validated technologies are already available to quantitate such end points. ${ }^{9,179}$ Considering patient-reported outcomes in a broader sense than has historically been the case, particularly in organ-preservation studies where treatment is randomly assigned, will provide useful information and facilitate clinical decision-making and subsequent improvement in treatment protocols.

\section{REFERENCES}

1. Jemal A, Murray $T$, Ward $E$, et al: Cancer statistics, 2005. CA Cancer J Clin 55:10-30, 2005

2. Myers EN, Suen JY, Myers JN, et al: Cancer of the Head and Neck (ed 4). Philadelphia, PA, Saunders, 2003

3. Piccirillo JF: Importance of comorbidity in head and neck cancer. Laryngoscope 110:593-602, 2000

4. Hong WK, Lippman SM, Itri LM, et al: Prevention of second primary tumors with isotretinoin in squamous-cell carcinoma of the head and neck. N Engl J Med 323:795-801, 1990

5. Lippman SM, Hong WK: Second malignant tumors in head and neck squamous cell carcinoma: The overshadowing threat for patients with earlystage disease. Int J Radiat Oncol Biol Phys 17:691694, 1989

6. Breitbart W, Holland J: Psychosocial aspects of head and neck cancer. Semin Oncol 15:61-69, 1988

7. Dropkin MJ: Body image and quality of life after head and neck cancer surgery. Cancer Pract 7:309-313, 1999

8. McNeil BJ, Weichselbaum R, Pauker SG: Speech and survival: Tradeoffs between quality and quantity of life in laryngeal cancer. N Engl J Med 305:982-987, 1981

9. Miller SD, Sulica L: General principles of rehabilitation of speech, voice, and swallowing after treatment of head and neck cancer, in Harrison LB, Sessions RB, Hong WK (eds): Head and Neck Cancer: A Multidisciplinary Approach (ed 2). Philadelphia, PA, Lippincott-Raven, 2004

10. DeSanto LW, Olsen KD, Perry WC, et al: Quality of life after surgical treatment of cancer of the larynx. Ann Otol Rhinol Laryngol 104:763-769, 1995

11. Carl J, Andersen $L J$, Pedersen $M$, et al: Prognostic factors of local control after radiotherapy in T1 glottic and supraglottic carcinoma of the larynx. Radiother Oncol 39:229-233, 1996

12. Cragle SP, Brandenburg JH: Laser cordectomy or radiotherapy: Cure rates, communication, and cost. Otolaryngol Head Neck Surg 108:648-654, 1993

13. Davis RK, Kelly SM, Parkin JL, et al: Selective management of early glottic cancer. Laryngoscope 100:1306-1309, 1990

14. de Graeff A, de Leeuw RJ, Ros WJ, et al: A prospective study on quality of life of laryngeal cancer patients treated with radiotherapy. Head Neck 21:291-296, 1999

15. Delsupehe KG, Zink I, Lejaegere $M$, et al: Voice quality after narrow-margin laser cordectomy compared with laryngeal irradiation. Otolaryngol Head Neck Surg 121:528-533, 1999

16. Dinshaw KA, Sharma V: Radiation therapy in early glottic carcinoma: Significance of prognostic factors and dose fractionation. Indian J Cancer 27 : 143-153, 1990

17. Eckel HE, Thumfart WF: Laser surgery for the treatment of larynx carcinomas: Indications, techniques, and preliminary results. Ann Otol Rhinol Laryngol 101:113-118, 1992

18. Fein $D A$, Lee $W R$, Hanlon $A L$, et al: Do overall treatment time, field size, and treatment energy influence local control of T1-T2 squamous cell carcinomas of the glottic larynx? Int J Radiat Oncol Biol Phys 34:823-831, 1996

19. Fujita M, Rudoltz MS, Canady DJ, et al: Second malignant neoplasia in patients with T1 glottic cancer treated with radiation. Laryngoscope 108:1853-1855, 1998
20. Gowda RV, Henk JM, Mais KL, et al: Three weeks radiotherapy for T1 glottic cancer: The Christie and Royal Marsden Hospital experience. Radiother Oncol 68:105-111, 2003

21. Hayakawa K, Mitsuhashi N, Akimoto T, et al: The effect of overall treatment time of radiation therapy on local control of T1-stage squamous cell carcinoma of the glottis. Laryngoscope 106:15451547, 1996

22. Laccourreye $O$, Veivers $D$, Hans $S$, et al: Chemotherapy alone with curative intent in patients with invasive squamous cell carcinoma of the pharyngolarynx classified as T1-T4NOMO complete clinical responders. Cancer 92:1504-1511, 2001

23. Marshak G, Brenner B, Shvero J, et al: Prognostic factors for local control of early glottic cancer: The Rabin Medical Center retrospective study on 207 patients. Int J Radiat Oncol Biol Phys 43:1009-1013, 1999

24. McGuirt WF, Blalock D, Koufman JA, et al: Comparative voice results after laser resection or irradiation of T1 vocal cord carcinoma. Arch Otolaryngol Head Neck Surg 120:951-955, 1994

25. Mendenhall WM, Amdur RJ, Morris CG, et al: T1-T2N0 squamous cell carcinoma of the glottic larynx treated with radiation therapy. J Clin Oncol 19:4029-4036, 2001

26. Morton RP: Laryngeal cancer: Quality-of-life and cost-effectiveness. Head Neck 19:243-250, 1997

27. Myers EN, Wagner RL, Johnson JT: Microlaryngoscopic surgery for T1 glottic lesions: A costeffective option. Ann Otol Rhinol Laryngol 103:2830, 1994

28. Nguyen $C$, Naghibzadeh $B$, Black MJ, et al: Carcinoma in situ of the glottic larynx: Excision or irradiation? Head Neck 18:225-228, 1996

29. Nishimura $Y$, Nagata $Y$, Okajima $K$, et al: Radiation therapy for T1,2 glottic carcinoma: Impact 
of overall treatment time on local control. Radiother Oncol 40:225-232, 1996

30. Nordgren $M$, Abendstein $H$, Jannert $M$, et al: Health-related quality of life five years after diagnosis of laryngeal carcinoma. Int J Radiat Oncol Biol Phys 56:1333-1343, 2003

31. Pearson BW, Salassa JR: Transoral laser microresection for cancer of the larynx involving the anterior commissure. Laryngoscope 113 1104-1112, 2003

32. Peretti G, Piazza C, Bolzoni A, et al: Analysis of recurrences in 322 Tis, T1, or T2 glottic carcinomas treated by carbon dioxide laser. Ann Otol Rhinol Laryngol 113:853-858, 2004

33. Rosier JF, Gregoire V, Counoy $\mathrm{H}$, et al: Comparison of external radiotherapy, laser microsurgery and partial laryngectomy for the treatment of T1N0M0 glottic carcinomas: A retrospective evaluation. Radiother Oncol 48:175-183, 1998

34. Rothfield RE, Myers EN, Johnson JT: Carcinoma in situ and microinvasive squamous cell carcinoma of the vocal cords. Ann Otol Rhinol Laryngol 100:793-796, 1991

35. Sagar SM, McKenna G, Nolan MC: A clinical audit of glottic cancer in Nova Scotia: A paradigm for effectiveness research. Clin Oncol (R Coll Radiol) 6:14-23, 1994

36. Schuller DE, Trudeau M, Bistline J, et al: Evaluation of voice by patients and close relatives following different laryngeal cancer treatments. J Surg Oncol 44:10-14, 1990

37. Slevin NJ, Vasanthan S, Dougal M: Relative clinical influence of tumor dose versus dose per fraction on the occurrence of late normal tissue morbidity following larynx radiotherapy. Int J Radiat Oncol Biol Phys 25:23-28, 1993

38. Steiner W: Results of curative laser microsurgery of laryngeal carcinomas. Am J Otolaryngo 14:116-121, 1993

39. Steiner W, Ambrosch $P$, Rodel RM, et al: Impact of anterior commissure involvement on local control of early glottic carcinoma treated by laser microresection. Laryngoscope 114:1485-1491, 2004

40. Stevens G, Castle G, O'Brien CJ: Treatment of early carcinoma of the vocal cords by radiotherapy. Australas Radiol 38:119-122, 1994

41. Stoeckli SJ, Guidicelli M, Schneider A, et al: Quality of life after treatment for early laryngea carcinoma. Eur Arch Otorhinolaryngol 258:96-99 2001

42. Wang CC, Efird JT: Does prolonged treatment course adversely affect local control of carcinoma of the larynx? Int J Radiat Oncol Biol Phys 29:657-660, 1994

43. Zeitels SM: Phonomicrosurgical treatment of early glottic cancer and carcinoma in situ. Am J Surg 172:704-709, 1996

44. Chevalier D, Watelet JB, Darras JA, et al: Supraglottic hemilaryngopharyngectomy plus radiation for the treatment of early lateral margin and pyriform sinus carcinoma. Head Neck 19:1-5, 1997

45. Fein DA, Mendenhall WM, Parsons JT, et al: T1-T2 squamous cell carcinoma of the glottic larynx treated with radiotherapy: A multivariate analysis of variables potentially influencing local control. Int J Radiat Oncol Biol Phys 25:605-611, 1993

46. Howell-Burke D, Peters LJ, Goepfert H, et al: T2 glottic cancer: Recurrence, salvage, and surviva after definitive radiotherapy. Arch Otolaryngol Head Neck Surg 116:830-835, 1990

47. Laccourreye $\mathrm{H}$, Laccourreye $\mathrm{O}$, Weinstein $\mathrm{G}$, et al: Supracricoid laryngectomy with cricohyoidopexy: A partial laryngeal procedure for selected supraglottic and transglottic carcinomas. Laryngoscope 100:735-741, 1990

48. Laccourreye $O$, Weinstein $G$, Brasnu $D$, et al: Vertical partial laryngectomy: A critical analysis of local recurrence. Ann Otol Rhinol Laryngol 100:6871, 1991

49. McLaughlin MP, Parsons JT, Fein DA, et al: Salvage surgery after radiotherapy failure in T1-T2 squamous cell carcinoma of the glottic larynx. Head Neck 18:229-235, 1996

50. Motta G, Esposito E, Cassiano B, et al: T1-T2-T3 glottic tumors: Fifteen years experience with CO2 laser. Acta Otolaryngol Suppl 527:155 159, 1997

51. Piquet JJ, Chevalier D: Subtotal laryngectomy with crico-hyoido-epiglotto-pexy for the treatment of extended glottic carcinomas. Am J Surg 162:357-361, 1991

52. Rudert HH, Werner JA: Endoscopic resections of glottic and supraglottic carcinomas with the CO2 laser. Eur Arch Otorhinolaryngol 252:146-148 1995

53. Slevin NJ, Hendry JH, Roberts SA, et al: The effect of increasing the treatment time beyond three weeks on the control of T2 and T3 laryngea cancer using radiotherapy. Radiother Oncol 24:215220, 1992

54. Spector JG, Sessions DG, Chao KS, et al: Management of stage II (T2NOM0) glottic carcinoma by radiotherapy and conservation surgery. Head Neck 21:116-123, 1999

55. Turesson I, Sandberg N, Mercke C, et al: Primary radiotherapy for glottic laryngeal carcinoma stage I and II: A retrospective study with specia regard to failure patterns. Acta Oncol 30:357-362, 1991

56. Viani L, Stell PM, Dalby JE: Recurrence after radiotherapy for glottic carcinoma. Cancer 67:577 584, 1991

57. Ambrosch $\mathrm{P}$, Kron M, Steiner W: Carbon dioxide laser microsurgery for early supraglottic carcinoma. Ann Otol Rhinol Laryngol 107:680-688, 1998

58. de Vincentiis M, Minni A, Gallo A, et al: Supracricoid partial laryngectomies: Oncologic and functional results. Head Neck 20:504-509, 1998

59. Eckel HE: Endoscopic laser resection of supraglottic carcinoma. Otolaryngol Head Neck Surg 117:681-687, 1997

60. Garden AS, Morrison WH, Ang KK, et al: Hyperfractionated radiation in the treatment of squamous cell carcinomas of the head and neck: A comparison of two fractionation schedules. Int $J$ Radiat Oncol Biol Phys 31:493-502, 1995

61. Hinerman RW, Mendenhall WM, Amdur RJ, et al: Carcinoma of the supraglottic larynx: Treatment results with radiotherapy alone or with planned neck dissection. Head Neck 24:456-467, 2002

62. Iro $H$, Waldfahrer $F$, Altendorf-Hofmann $A$, et al: Transoral laser surgery of supraglottic cancer: Follow-up of 141 patients. Arch Otolaryngol Head Neck Surg 124:1245-1250, 1998

63. Kim RY, Marks ME, Salter MM: Early-stage glottic cancer: Importance of dose fractionation in radiation therapy. Radiology 182:273-275, 1992

64. Le QT, Fu KK, Kroll S, et al: Influence of fraction size, total dose, and overall time on loca control of T1-T2 glottic carcinoma. Int J Radiat Oncol Biol Phys 39:115-126, 1997

65. Lee NK, Goepfert H, Wendt CD: Supraglottic laryngectomy for intermediate-stage cancer: UT MD Anderson Cancer Center experience with combined therapy. Laryngoscope 100:831-836, 1990
66. Lutz CK, Johnson JT, Wagner $R L$, et al: Supraglottic carcinoma: Patterns of recurrence. Ann Otol Rhinol Laryngol 99:12-17, 1990

67. Mancuso AA, Mukherji SK, Schmalfuss I, et al: Preradiotherapy computed tomography as a predictor of local control in supraglottic carcinoma. J Clin Oncol 17:631-637, 1999

68. Motta G, Esposito E, Testa D, et al: CO2 laser treatment of supraglottic cancer. Head Neck 26:442-446, 2004

69. Parsons JT, Mendenhall WM, Stringer SP, et al: Radiotherapy alone for moderately advanced laryngeal cancer (T2-T3). Semin Radiat Oncol 2:158 162,1992

70. Parsons JT, Mendenhall WM, Stringer SP, et al: Salvage surgery following radiation failure in squamous cell carcinoma of the supraglottic larynx. Int J Radiat Oncol Biol Phys 32:605-609, 1995

71. Rudert HH, Werner JA, Hoft S: Transoral carbon dioxide laser resection of supraglottic carcinoma. Ann Otol Rhinol Laryngol 108:819-827, 1999

72. Spriano G, Antognoni $P$, Piantanida $R$, et al: Conservative management of T1-T2N0 supraglottic cancer: A retrospective study. Am J Otolaryngol 18:299-305, 1997

73. van der Voet JC, Keus RB, Hart AA, et al: The impact of treatment time and smoking on local control and complications in T1 glottic cancer. Int J Radiat Oncol Biol Phys 42:247-255, 1998

74. Wendt CD, Peters LJ, Ang KK, et al: Hyperfractionated radiotherapy in the treatment of squamous cell carcinomas of the supraglottic larynx. Int $J$ Radiat Oncol Biol Phys 17:1057-1062, 1989

75. Yu E, Shenouda G, Beaudet MP, et al: Impact of radiation therapy fraction size on local contro of early glottic carcinoma. Int J Radiat Oncol Biol Phys 37:587-591, 1997

76. Fu KK, Pajak TF, Trotti A, et al: A Radiation Therapy Oncology Group (RTOG) phase III randomized study to compare hyperfractionation and two variants of accelerated fractionation to standard fractionation radiotherapy for head and neck squamous cell carcinomas: First report of RTOG 9003. Int J Radiat Oncol Biol Phys 48:7-16, 2000

77. Forastiere $A A$, Goepfert $H$, Maor $M$, et al: Concurrent chemotherapy and radiotherapy for organ preservation in advanced laryngeal cancer. N Engl J Med 349:2091-2098, 2003

78. Induction chemotherapy plus radiation compared with surgery plus radiation in patients with advanced laryngeal cancer: The Department of Veterans Affairs Laryngeal Cancer Study Group. N Eng J Med 324:1685-1690, 1991

79. Adelstein DJ, Lavertu P Saxton JP, et al: Mature results of a phase III randomized trial comparing concurrent chemoradiotherapy with radiation therapy alone in patients with stage III and IV squamous cell carcinoma of the head and neck. Cancer 88:876-883, 2000

80. Adelstein DJ, Saxton JP, Lavertu P, et al: A phase III randomized trial comparing concurrent chemotherapy and radiotherapy with radiotherapy alone in resectable stage III and IV squamous cel head and neck cancer: Preliminary results. Head Neck 19:567-575, 1997

81. Lefebvre JL, Chevalier D, Luboinski B, et al Larynx preservation in pyriform sinus cancer: Preliminary results of a European Organization for Research and Treatment of Cancer phase III trialEORTC Head and Neck Cancer Cooperative Group. J Natl Cancer Inst 88:890-899, 1996

82. Richard JM, Sancho-Garnier H, Pessey JJ, et al: Randomized trial of induction chemotherapy in larynx carcinoma. Oral Oncol 34:224-228, 1998 
83. Bhalavat $R L$, Fakih $A R$, Mistry $R C$, et al: Radical radiation vs surgery plus post-operative radiation in advanced (resectable) supraglottic larynx and pyriform sinus cancer: A prospective randomized study. Eur J Surg Oncol 29:750-756, 2003

84. Brizel DM, Albers ME, Fisher SR, et al: Hyperfractionated irradiation with or without concurrent chemotherapy for locally advanced head and neck cancer. N Engl J Med 338:1798-1804, 1998

85. Jeremic B, Shibamoto $Y$, Milicic B, et al: Hyperfractionated radiation therapy with or without concurrent low-dose daily cisplatin in locally advanced squamous cell carcinoma of the head and neck: A prospective randomized trial. J Clin Oncol 18:1458-1464, 2000

86. Bourhis J, Etessami $A$, Wilbault $P$, et al: Altered fractionated radiotherapy in the management of head and neck carcinomas: Advantages and limitations. Curr Opin Oncol 16:215-219, 2004

87. Browman GP, Hodson DI, Mackenzie RJ, et al: Choosing a concomitant chemotherapy and radiotherapy regimen for squamous cell head and neck cancer: A systematic review of the published literature with subgroup analysis. Head Neck 23:579-589, 2001

88. Pignon JP, Bourhis J, Domenge C, et al: Chemotherapy added to locoregional treatment for head and neck squamous-cell carcinoma: Three metaanalyses of updated individual data-MACH-NC Collaborative Group: Meta-analysis of chemotherapy on head and neck cancer. Lancet 355:949-955, 2000

89. Bron L, Brossard E, Monnier P, et al: Supracricoid partial laryngectomy with cricohyoidoepiglottopexy and cricohyoidopexy for glottic and supraglottic carcinomas. Laryngoscope 110:627-634, 2000

90. Davis RK, Kriskovich MD, Galloway EB III, et al: Endoscopic supraglottic laryngectomy with postoperative irradiation. Ann Otol Rhinol Laryngol 113: 132-138, 2004

91. Dufour X, Hans S, De Mones E, et al: Local control after supracricoid partial laryngectomy for "advanced" endolaryngeal squamous cell carcinoma classified as T3. Arch Otolaryngol Head Neck Surg 130:1092-1099, 2004

92. Flores TC, Wood BG, Levine HL, et al: Factors in successful deglutition following supraglottic laryngeal surgery. Ann Otol Rhinol Laryngol 91:579583, 1982

93. Karp DD, Vaughan CW, Carter $R$, et al: Larynx preservation using induction chemotherapy plus radiation therapy as an alternative to laryngectomy in advanced head and neck cancer: A long-term follow-up report. Am J Clin Oncol 14:273-279, 1991

94. Laccourreye O, Brasnu D, Biacabe B, et al: Neo-adjuvant chemotherapy and supracricoid partial laryngectomy with cricohyoidopexy for advanced endolaryngeal carcinoma classified as T3-T4: 5-year oncologic results. Head Neck 20:595-599, 1998

95. Laccourreye $O$, Hans S, Borzog-Grayeli A, et al: Complications of postoperative radiation therapy after partial laryngectomy in supraglottic cancer: A long-term evaluation. Otolaryngol Head Neck Surg 122:752-757, 2000

96. List MA, Ritter-Sterr CA, Baker TM, et al: Longitudinal assessment of quality of life in laryngeal cancer patients. Head Neck 18:1-10, 1996

97. Marioni G, Marchese-Ragona R, Ottaviano $G$, et al: Supracricoid laryngectomy: Is it time to define guidelines to evaluate functional results? A review. Am J Otolaryngol 25:98-104, 2004

98. McConnel FM, Mendelsohn MS, Logemann JA: Manofluorography of deglutition after supraglottic laryngectomy. Head Neck Surg 9:142-150, 1987

99. Pfister DG, Strong E, Harrison L, et al: Larynx preservation with combined chemotherapy and ra- diation therapy in advanced but resectable head and neck cancer. J Clin Oncol 9:850-859, 1991

100. Rademaker AW, Logemann JA, Pauloski BR, et al: Recovery of postoperative swallowing in patients undergoing partial laryngectomy. Head Neck 15:325-334, 1993

101. Sewnaik $A$, van den Brink JL, Wieringa $M H$, et al: Surgery for recurrent laryngeal carcinoma after radiotherapy: Partial laryngectomy or total laryngectomy for a better quality of life? Otolaryngol Head Neck Surg 132:95-98, 2005

102. Terrell JE, Fisher SG, Wolf GT: Long-term quality of life after treatment of laryngeal cancer: The Veterans Affairs Laryngeal Cancer Study Group. Arch Otolaryngol Head Neck Surg 124:964-971, 1998

103. Vachin F, Hans S, Atlan D, et al: Long term results of exclusive chemotherapy for glottic squamous cell carcinoma complete clinical responders after induction chemotherapy [French]. Ann Otolaryngol Chir Cervicofac 121:140-147, 2004

104. Vokes EE, Stenson $K$, Rosen FR, et al: Weekly carboplatin and paclitaxel followed by concomitant paclitaxel, fluorouracil, and hydroxyurea chemoradiotherapy: Curative and organ-preserving therapy for advanced head and neck cancer. J Clin Oncol 21:320-326, 2003

105. Weber RS, Berkey BA, Forastiere A, et al: Outcome of salvage total laryngectomy following organ preservation therapy: The Radiation Therapy Oncology Group trial 91-11. Arch Otolaryngol Head Neck Surg 129:44-49, 2003

106. Weinstein GS, El-Sawy MM, Ruiz C, et al: Laryngeal preservation with supracricoid partial laryngectomy results in improved quality of life when compared with total laryngectomy. Laryngoscope 111:191-199, 2001

107. Weinstein GS, Laccourreye $O$, Ruiz $C$, et al: Larynx preservation with supracricoid partial laryngectomy with cricohyoidoepiglottopexy: Correlation of videostroboscopic findings and voice parameters. Ann Otol Rhinol Laryngol 111:1-7, 2002

108. Lavertu $P$, Bonafede JP, Adelstein DJ, et al: Comparison of surgical complications after organpreservation therapy in patients with stage III or IV squamous cell head and neck cancer. Arch Otolaryngol Head Neck Surg 124:401-406, 1998

109. Fein $D A$, Hanlon $A L$, Lee $W R$, et al: Neck failure in T2NO squamous cell carcinoma of the true vocal cords: The Fox Chase experience and review of the literature. Am J Clin Oncol 20:154-157, 1997

110. Garden AS, Forster K, Wong PF, et al: Results of radiotherapy for T2NO glottic carcinoma: Does the "2" stand for twice-daily treatment? Int J Radiat Oncol Biol Phys 55:322-328, 2003

111. Johansen LV, Grau C, Overgaard J: Glottic carcinoma-patterns of failure and salvage treatment after curative radiotherapy in 861 consecutive patients. Radiother Oncol 63:257-267, 2002

112. McGuirt WF, McCabe BF: Significance of node biopsy before definitive treatment of cervical metastatic carcinoma. Laryngoscope 88:594-597, 1978

113. End results of a prospective trial on elective lateral neck dissection vs type III modified radical neck dissection in the management of supraglottic and transglottic carcinomas: Brazilian Head and Neck Cancer Study Group. Head Neck 21:694-702, 1999

114. Argiris A, Stenson KM, Brockstein BE, et al: Neck dissection in the combined-modality therapy of patients with locoregionally advanced head and neck cancer. Head Neck 26:447-455, 2004

115. Armstrong J, Pfister D, Strong E, et al: The management of the clinically positive neck as part of a larynx preservation approach. Int J Radiat Oncol Biol Phys 26:759-765, 1993

116. Barkley HT Jr, Fletcher GH, Jesse $\mathrm{RH}$, et al: Management of cervical lymph node metastases in squamous cell carcinoma of the tonsillar fossa, base of tongue, supraglottic larynx, and hypopharynx. Am J Surg 124:462-467, 1972

117. Bernier J, Thames HD, Smith $C D$, et al: Tumor response, mucosal reactions and late effects after conventional and hyperfractionated radiotherapy. Radiother Oncol 47:137-143, 1998

118. Brizel DM, Prosnitz RG, Hunter $S$, et al: Necessity for adjuvant neck dissection in setting of concurrent chemoradiation for advanced head-andneck cancer. Int J Radiat Oncol Biol Phys 58:14181423, 2004

119. Chan AW, Ancukiewicz M, Carballo N, et al: The role of postradiotherapy neck dissection in supraglottic carcinoma. Int J Radiat Oncol Biol Phys 50:367-375, 2001

120. Ellis ER, Mendenhall WM, Rao PV, et al: Incisional or excisional neck-node biopsy before definitive radiotherapy, alone or followed by neck dissection. Head Neck 13:177-183, 1991

121. Greven KM, Williams DW III, McGuirt WF Sr, et al: Serial positron emission tomography scans following radiation therapy of patients with head and neck cancer. Head Neck 23:942-946, 2001

122. Johnson CR, Silverman LN, Clay LB, et al: Radiotherapeutic management of bulky cervical lymphadenopathy in squamous cell carcinoma of the head and neck: Is postradiotherapy neck dissection necessary? Radiat Oncol Investig 6:52-57, 1998

123. Kligerman J, Olivatto LO, Lima RA, et al: Elective neck dissection in the treatment of T3/T4 N0 squamous cell carcinoma of the larynx. Am J Surg 170:436-439, 1995

124. Kutler DI, Patel SG, Shah JP: The role of neck dissection following definitive chemoradiation. Oncology (Williston Park) 18:993-998, 999, 1003-1004, 1007, 2004

125. Lavertu $P$, Adelstein DJ, Saxton JP, et al: Management of the neck in a randomized trial comparing concurrent chemotherapy and radiotherapy with radiotherapy alone in resectable stage III and IV squamous cell head and neck cancer. Head Neck 19:559-566, 1997

126. Levendag $P$, Sessions R, Vikram B, et al: The problem of neck relapse in early stage supraglottic larynx cancer. Cancer 63:345-348, 1989

127. Levendag PC, Hoekstra CJ, Eijkenboom WM, et al: Supraglottic larynx cancer, T1-4 N0, treated by radical radiation therapy. Problem of neck relapse. Acta Oncol 27:253-260, 1988

128. Mabanta SR, Mendenhall WM, Stringer SP, et al: Salvage treatment for neck recurrence after irradiation alone for head and neck squamous cell carcinoma with clinically positive neck nodes. Head Neck 21:591-594, 1999

129. Mack Y, Parsons JT, Mendenhall WM, et al: Squamous cell carcinoma of the head and neck: Management after excisional biopsy of a solitary metastatic neck node. Int J Radiat Oncol Biol Phys 25:619-622, 1993

130. McHam SA, Adelstein DJ, Rybicki LA, et al: Who merits a neck dissection after definitive chemoradiotherapy for N2-N3 squamous cell head and neck cancer? Head Neck 25:791-798, 2003

131. Mendenhall WM, Million RR, Cassisi NJ: Squamous cell carcinoma of the head and neck treated with radiation therapy: The role of neck dissection for clinically positive neck nodes. Int J Radiat Oncol Biol Phys 12:733-740, 1986 
132. Mendenhall WM, Parsons JT, Mancuso AA et al: Definitive radiotherapy for T3 squamous cell carcinoma of the glottic larynx. J Clin Oncol 15:23942402, 1997

133. Mendenhall WM, Parsons JT, Stringer SP, et al: Squamous cell carcinoma of the head and neck treated with irradiation: Management of the neck. Semin Radiat Oncol 2:163-170, 1992

134. Mendenhall WM, Villaret DB, Amdur RJ, et al: Planned neck dissection after definitive radiotherapy for squamous cell carcinoma of the head and neck. Head Neck 24:1012-1018, 2002

135. Ojiri $H$, Mendenhall WM, Stringer SP, et al: Post-RT CT results as a predictive model for the necessity of planned post-RT neck dissection in patients with cervical metastatic disease from squamous cell carcinoma. Int J Radiat Oncol Biol Phys 52:420-428, 2002

136. Peters LJ, Weber RS, Morrison WH, et al: Neck surgery in patients with primary oropharyngea cancer treated by radiotherapy. Head Neck 18:552 559, 1996

137. Redaelli de Zinis LO, Nicolai $P$, Tomenzoli $D$, et al: The distribution of lymph node metastases in supraglottic squamous cell carcinoma: Therapeutic implications. Head Neck 24:913-920, 2002

138. Sykes AJ, Slevin NJ, Gupta NK, et al: 331 cases of clinically node-negative supraglottic carcinoma of the larynx: A study of a modest size fixed field radiotherapy approach. Int J Radiat Oncol Biol Phys 46:1109-1115, 2000

139. Weber PC, Johnson JT, Myers EN: The impact of bilateral neck dissection on pattern of recurrence and survival in supraglottic carcinoma. Arch Otolaryngol Head Neck Surg 120:703-706, 1994

140. Wolf GT, Fisher SG: Effectiveness of salvage neck dissection for advanced regional metastases when induction chemotherapy and radiation are used for organ preservation. Laryngoscope 102:934-939, 1992

141. Wong RJ, Lin DT, Schoder $H$, et al: Diagnostic and prognostic value of [(18)F]fluorodeoxyglucose positron emission tomography for recurrent head and neck squamous cell carcinoma. J Clin Oncol 20:4199-4208, 2002

142. Yao M, Graham MM, Hoffman HT, et al: The role of post-radiation therapy FDG PET in prediction of necessity for post-radiation therapy neck dissection in locally advanced head-and-neck squamous cell carcinoma. Int J Radiat Oncol Biol Phys 59:10011010, 2004

143. Bernier J, Domenge $C$, Ozsahin $M$, et al: Postoperative irradiation with or without concomitant chemotherapy for locally advanced head and neck cancer. N Engl J Med 350:1945-1952, 2004

144. Cooper JS, Pajak TF, Forastiere AA, et al: Postoperative concurrent radiotherapy and chemotherapy for high-risk squamous-cell carcinoma of the head and neck. N Engl J Med 350:1937-1944, 2004

145. Bachaud J-M, Cohen-Jonathan E, Alzieu C et al: Combined postoperative radiotherapy and weekly cisplatin infusion for locally advanced head and neck carcinoma: Final report of the randomized trial. Int J Rad Oncol Biol Phys 36:999-1004, 1996

146. Alsner J, Sorensen SB, Overgaard J: TP53 mutation is related to poor prognosis after radiotherapy, but not surgery, in squamous cell carcinoma of the head and neck. Radiother Oncol 59:179-185, 2001

147. Benninger MS, Gillen J, Thieme $P$, et al: Factors associated with recurrence and voice quality following radiation therapy for T1 and T2 glottic carcinomas. Laryngoscope 104:294-298, 1994
148. Bradford CR, Zhu S, Wolf GT, et al: Overexpression of p53 predicts organ preservation using induction chemotherapy and radiation in patients with advanced laryngeal cancer: Department of Veterans Affairs Laryngeal Cancer Study Group. Otolaryngol Head Neck Surg 113:408-412, 1995

149. Browman GP, Mohide EA, Willan A, et al: Association between smoking during radiotherapy and prognosis in head and neck cancer: A follow-up study. Head Neck 24:1031-1037, 2002

150. Browman GP, Wong G, Hodson I, et al: Influence of cigarette smoking on the efficacy of radiation therapy in head and neck cancer. N Eng J Med 328:159-163, 1993

151. Cabelguenne $A$, Blons $H$, de Waziers I, et al: p53 alterations predict tumor response to neoadjuvant chemotherapy in head and neck squamous cel carcinoma: A prospective series. J Clin Oncol 18 1465-1473, 2000

152. Cho El, Sasaki CT, Haffty BG: Prognostic significance of pretreatment hemoglobin for local control and overall survival in T1-T2N0 larynx cancer treated with external beam radiotherapy. Int J Radiat Oncol Biol Phys 58:1135-1140, 2004

153. Fein DA, Lee WR, Hanlon $A L$, et al: Pretreatment hemoglobin level influences local control and survival of T1-T2 squamous cell carcinomas of the glottic larynx. J Clin Oncol 13:2077-2083, 1995

154. Hermans R, Van den Bogaert W, Rijnders $A$ et al: Predicting the local outcome of glottic squamous cell carcinoma after definitive radiation therapy: Value of computed tomography-determined tumour parameters. Radiother Oncol 50:39-46, 1999

155. Hirvikoski P, Kumpulainen E, Virtaniemi J, et al: p53 expression and cell proliferation as prognostic factors in laryngeal squamous cell carcinoma J Clin Oncol 15:3111-3120, 1997

156. Johansen LV, Grau C, Overgaard J: Laryngeal carcinoma: Multivariate analysis of prognostic factors in 1252 consecutive patients treated with primary radiotherapy. Acta Oncol 42:771-778, 2003

157. Kersh CR, Kelly MD, Hahn SS, et al: Early glottic carcinoma: Patterns and predictors of relapse after definitive radiotherapy. South Med J 83:374-378, 1990

158. Ljumanovic R, Langendijk JA, Schenk $B$, et al: Supraglottic carcinoma treated with curative radiation therapy: Identification of prognostic groups with MR imaging. Radiology 232:440-448, 2004

159. Mendenhall WM, Morris CG, Amdur RJ, et al: Parameters that predict local control after definitive radiotherapy for squamous cell carcinoma of the head and neck. Head Neck 25:535-542, 2003

160. Mendenhall WM, Parsons JT, Mancuso AA et al: Radiotherapy for squamous cell carcinoma of the supraglottic larynx: An alternative to surgery. Head Neck 18:24-35, 1996

161. Murakami R, Baba $Y$, Furusawa $M$, et al: Early glottic squamous cell carcinoma: Predictive value of MR imaging for the rate of 5-year local control with radiation therapy. Acta Radiol 41:38-44, 2000

162. Osman I, Sherman E, Singh B, et al: Alteration of p53 pathway in squamous cell carcinoma of the head and neck: Impact on treatment outcome in patients treated with larynx preservation intent J Clin Oncol 20:2980-2987, 2002

163. Pameijer FA, Mancuso AA, Mendenhall WM et al: Can pretreatment computed tomography predict local control in T3 squamous cell carcinoma of the glottic larynx treated with definitive radiotherapy? Int J Radiat Oncol Biol Phys 37:1011-1021, 1997
164. Robbins KT, Davidson W, Peters LJ, et al: Conservation surgery for T2 and T3 carcinomas of the supraglottic larynx. Arch Otolaryngol Head Neck Surg 114:421-426, 1988

165. Stevens $\mathrm{MH}$, Gardner JW, Parkin JL, et al: Head and neck cancer survival and life-style change. Arch Otolaryngol 109:746-749, 1983

166. Tarnawski R, Skladowski K, Maciejewski B: Prognostic value of hemoglobin concentration in radiotherapy for cancer of supraglottic larynx. Int $J$ Radiat Oncol Biol Phys 38:1007-1011, 1997

167. Trask DK, Wolf GT, Bradford CR, et al: Expression of $\mathrm{Bcl}-2$ family proteins in advanced laryngeal squamous cell carcinoma: Correlation with response to chemotherapy and organ preservation. Laryngoscope 112:638-644, 2002

168. Warde $P, O$ 'Sullivan $B$, Bristow RG, et al: T1/T2 glottic cancer managed by external beam radiotherapy: The influence of pretreatment hemoglobin on local control. Int J Radiat Oncol Biol Phys 41:347-353, 1998

169. Wolf GT, Makuch RW, Baker SR: Predictive factors for tumor response to preoperative chemotherapy in patients with head and neck squamous carcinoma: The Head and Neck Contracts Program. Cancer 54:2869-2877, 1984

170. Spaulding MB, Fischer SG, Wolf GT: Tumor response, toxicity, and survival after neoadjuvant organ-preserving chemotherapy for advanced laryngeal carcinoma: The Department of Veterans Affairs Cooperative Laryngeal Cancer Study Group. J Clin Oncol 12:1592-1599, 1994

171. Truelson JM, Fisher SG, Beals TE, et al: DNA content and histologic growth pattern correlate with prognosis in patients with advanced squamous cell carcinoma of the larynx: The Department of Veterans Affairs Cooperative Laryngeal Cancer Study Group. Cancer 70:56-62, 1992

172. Gillespie MB, Bordsky MB, Day $T A$, et al: Swallowing-related quality of life after head and neck cancer treatment. Laryngoscope 114:1362-1367, 2004

173. Terrell JE, Ronis DL, Fowler KE, et al: Clinical predictors of quality of life in patients with head and neck cancer. Arch Otolaryngol Head Neck Surg 130:401-408, 2004

174. Eisbruch A, Lyden T, Bradford CR, et al: Objective assessment of swallowing dysfunction and aspiration after radiation concurrent with chemotherapy for head-and-neck cancer. Int J Radiation Oncol Biol Phys 53:23-28, 2002

175. Nguyen NP, Molrz CC, Frank C, et al: Dysphagia following chemoradiation for locally advanced head and neck cancer. Ann Oncol 15:383-388, 2004

176. Smith RV, Kotz T, Beitler JJ, et al: Long-term swallowing problems after organ preservation therapy with concomitant radiation therapy and intravenous hydroxyurea: Initial results. Arch Otolaryngol Head Neck Surg 126:384-389, 2000

177. Eisbruch A, Schwartz M, Rasch $C$, et al: Dysphagia and aspiration after chemoradiotherapy for head-and-neck cancer: Which anatomic structures are affected and can they be spared by IMRT? Int J Radiation Oncol Biol Phys 60:1425-1439, 2004

178. Smith RV, Goldman SY, Beitler JJ, et al: Decreased short- and long-term swallowing problems with altered radiotherapy dosing used in an organsparing protocol for advanced pharyngeal carcinoma. Arch Otolaryngol Head Neck Surg 130:831-836, 2004

179. Fung $\mathrm{K}$, Terrell JE: Outcomes research in head and neck cancer. ORL J Otorhinolaryngol Relat Spec 66:207-213, 2004 


\section{Acknowledgment}

The Expert Panel members wish to thank Dr David M. Brizel, Dr George P. Browman, Dr Brian Burkey, Dr Avraham Eisbruch, Dr Jan S. Lewin, Dr Bruce D. Minsky, Dr James Netterville, Dr Michael N. Neuss, Dr Jay Piccirillo, Dr Andy Trotti, Dr Jan B. Vermorken, Dr Jamie H.

Von Roenn, Dr Randal S. Weber, and Dr Ernest Weymuller for their thoughtful reviews of earlier drafts.

The Expert Panel members also wish to express their gratitude to Dr Karen Fu and Dr Yungpo Bernard Su for their constructive input and assistance in preparation of the guideline.

\section{Appendix}

\begin{tabular}{|ll|}
\hline \multicolumn{1}{|c|}{ Anvestigator } & \\
\hline David G. Pfister, MD, Co-Chair & \\
\hline Gregory T. Wolf, MD, Co-Chair & Memorial Sloan-Kettering Cancer Center \\
David J. Adelstein, MD & University of Michigan Hospital \\
Kie-Kian Ang, MD, PhD & Cleveland Clinic Foundation \\
Gary L. Clayman, MD & University of Texas M.D. Anderson Cancer Center \\
Susan G. Fisher, PhD & University of Texas M.D. Anderson Cancer Center \\
Arlene A. Forastiere, MD & University of Rochester \\
Louis B. Harrison, MD & Johns Hopkins University, The Sidney Kimmel Cancer Center \\
Scott A. Laurie, MD & Beth Israel Health Care System \\
Jean-Louis Lefebvre, MD & The Ottawa Hospital Regional Cancer Centre \\
Nancy Leupold, MS & Centre Oscar-Lambret \\
Marcy A. List, PhD & Support for People with Oral and Head and Neck Cancer (SPONHC) \\
William M. Mendenhall, MD & University of Chicago \\
Bernard O'Malley, MD & University of Florida \\
Marshall R. Posner, MD & Princeton Radiology Association \\
Michael A. Schwartz, MD & Dana-Farber Cancer Institute \\
Snehal Patel, MD & Oncology Hematology Associates \\
Gregory S. Weinstein, MD & Memorial Sloan-Kettering Cancer Center \\
\hline & University of Pennsylvania School of Medicine \\
\hline
\end{tabular}




\section{Authors' Disclosures of Potential Conflicts of Interest}

Although all authors completed the disclosure declaration, the following authors or their immediate family members indicated a financial interest. No conflict exists for drugs or devices used in a study if they are not being evaluated as part of the investigation. For a detailed description of the disclosure categories, or for more information about ASCO's conflict of interest policy, please refer to the Author Disclosure Declaration and the Disclosures of Potential Conflicts of Interest section in Information for Contributors.

\begin{tabular}{|c|c|c|c|c|c|c|c|c|}
\hline Authors & Employment & Leadership & Consultant & Stock & Honoraria & Research Funds & Testimony & Other \\
\hline David G. Pfister & & & Sanofi-Aventis (A) & & & Imclone (C) & & \\
\hline \multicolumn{9}{|l|}{ Scott A. Laurie* } \\
\hline \multicolumn{9}{|l|}{$\begin{array}{l}\text { William M. } \\
\text { Mendenhall* }\end{array}$} \\
\hline David G. Adelstein & & & & & & AstraZeneca $(\mathrm{C})$ & & \\
\hline \multicolumn{9}{|l|}{ Gary L. Clayman* } \\
\hline \multicolumn{9}{|l|}{ Susan G. Fisher* } \\
\hline Arlene A. Forastiere & & & & & & $\begin{array}{c}\text { Pfizer (C); } \\
\text { AstraZeneca (C) }\end{array}$ & & \\
\hline \multicolumn{9}{|l|}{ Bernard 0. O'Malley* } \\
\hline \multicolumn{9}{|l|}{ Snehal Patel* } \\
\hline Marshall R. Posner & & & $\begin{array}{c}\text { GlaxoSmithKline } \\
\text { (A); Amgen (A); } \\
\text { Sanofi-Aventis (A); } \\
\text { Caltech (A); Med } \\
\text { Immune (A) }\end{array}$ & & $\begin{array}{c}\text { Amgen (A); Sanofi- } \\
\text { Aventis (A); Bristol- } \\
\text { Myers Squibb (A); } \\
\text { Med Immune (A) }\end{array}$ & & & \\
\hline \multicolumn{9}{|l|}{ Michael A. Schwartz* } \\
\hline Gregory T. Wolf* & & & & & & & & \\
\hline \multicolumn{9}{|c|}{$\begin{array}{lll}\text { Dollar Amount Codes } & \text { (A) }<\$ 10,000 & \text { (B) } \$ 10,000-99,999\end{array}$} \\
\hline
\end{tabular}

*No significant financial relationships to disclose.

\section{Author Contributions}

Conception and design: David G. Pfister, Gregory S. Weinstein, William M. Mendenhall, David J. Adelstein, K. Kian Ang, Gary L. Clayman, Susan G. Fisher, Arlene A. Forastiere, Louis B. Harrison, Jean-Louis Lefebvre, Nancy Leupoid, Marcy A. List, Bernard O. O’Malley, Marshall R. Posner, Michael A. Schwartz, Gregory T. Wolf

Collection and assembly of data: David G. Pfister, Scott A. Laurie, Gregory S. Weinstein, William M. Mendenhall, David J. Adelstein, K. Kian Ang, Gary L. Clayman, Susan G. Fisher, Arlene A. Forastiere, Louis B. Harrison, Jean-Louis Lefebvre, Nancy Leupold, Marcy A. List, Bernard O. O'Malley, Snehal Patel, Marshall R. Posner, Michael A. Schwartz, Gregory T. Wolf

Data analysis and interpretation: David G. Pfister, Scott A. Laurie, Gregory S. Weinstein, William M. Mendenhall, David J. Adelstein, K. Kian Ang, Gary L. Clayman, Susan G. Fisher, Arlene A. Forastiere, Louis B. Harrison, Jean-Louis Lefebvre, Nancy Leupold, Marcy A. List, Bernard O. O'Malley, Snehal Patel, Marshall R. Posner, Michael A. Schwartz, Gregory T. Wolf

Manuscript writing: David G. Pfister, Scott A. Laurie, Gregory S. Weinstein, William M. Mendenhall, David J. Adelstein, K. Kian Ang, Gary L. Clayman, Susan G. Fisher, Arlene A. Forastiere, Louis B. Harrison, Jean-Louis Lefebvre, Nancy Leupold, Marcy A. List, Bernard O. O’Malley, Snehal Patel, Marshall R. Posner, Michael A. Schwartz, Gregory T. Wolf

Final approval of manuscript: David G. Pfister, Scott A. Laurie, Gregory S. Weinstein, William M. Mendenhall, David J. Adelstein, K. Kian Ang, Gary L. Clayman, Susan G. Fisher, Arlene A. Forastiere, Louis B. Harrison, Jean-Louis Lefebvre, Nancy Leupold, Marcy A. List, Bernard O. O’Malley, Snehal Patel, Marshall R. Posner, Michael A. Schwartz, Gregory T. Wolf 